\title{
COMPARATIVE ANALYSIS OF MORPHOLOGICAL INDICATORS OF STREET WORKOUT ATHLETES WITH DIFFERENT TRAINING EXPERIENCE
}

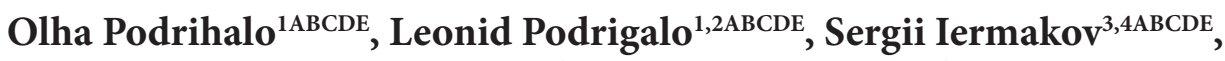 \\ Zhanna Sotnikova-Meleshkina ${ }^{2 \mathrm{CDE}}$, Konstantin Sokol ${ }^{\mathrm{CDE}}$, \\ Olexandr Podavalenko ${ }^{1 \mathrm{CDE}}$, Olexsandr Halashko ${ }^{6 \mathrm{CDE}}$, Tetiana Yermakova ${ }^{4 \mathrm{ACD}}$ \\ ${ }^{1}$ Kharkiv State Academy of Physical Culture \\ ${ }^{2}$ V.N. Karazin Kharkiv National University \\ ${ }^{3}$ Gdansk University of Physical Education and Sports \\ ${ }^{4}$ Kharkiv State Academy of Design and Arts \\ ${ }^{5}$ Kharkiv National Medical University \\ ${ }^{6}$ State Biotechnological University \\ Authors' Contribution: A - Study design; B - Data collection; C - Statistical analysis; D - Manuscript Preparation; E - Funds Collection
}

Corresponding Author: Leonid Podrigalo, E-mail: leonid.podrigalo@gmail.com

Accepted for Publication: December 2, 2021

Published: December 25, 2021

DOI: 10.17309/tmfv.2021.4.09

\begin{abstract}
Purpose. The purpose of the article is a comparative analysis of the morphological indicators of street workout (StW) athletes with different training experience (TE).

Materials and methods. The study involved StW athletes $(\mathrm{n}=27)$. Athletes were divided into two groups: StW-1 $(\mathrm{n}=13$, age $15.15 \pm 0.44$ years, TE $1.56 \pm 0.22$ years); StW-2 $(\mathrm{n}=14$, age $16.57 \pm 0.48$ years, TE $2.64 \pm 0.53$ years $)$. The body length and body mass were measured; the level and harmony of physical development were evaluated. The regression method was used. The handgrip was evaluated by hand dynamometry indicators Camry EH101 electronic dynamometer (China). The handgrip was measured by the maximum grip frequency in $10 \mathrm{~s}$ the electronic device "Kepai" (China). The content of muscle and adipose tissue were determined by the body composition monitor OMRON BF-511 (Japan).

Results. The average value of the strength index in the StW-1 was more than $60 \%$, and in the StW- 2 was more than $70 \%$. The StW-2 had a significant excess of the hand dynamometry, power index, impulse index of both hands; index of static and dynamic grip of the left hand; specific weight of muscles. The average level of physical development was observed in $(61.54 \pm 13.49) \%$, above the average was observed in $(23.08 \pm 11.69) \%$ of StW-1. Harmonious physical development had (38.46 \pm 13.49$) \%$. In StW-2, the average level of physical development had $(64.29 \pm 12.81) \%$, above the average had $(21.43 \pm 10.97) \%$. Harmonious physical development had $(50.00 \pm 13.36) \%$. In StW-1 $(46.15 \pm 13.83) \%$ had a normal fat content and a fat level below normal. In StW-2, the normal fat content had $(30.77 \pm 12.80) \%$, and the low adipose tissue content was $(69.23 \pm 12.80) \%$.

Conclusions. All athletes had a high content of muscle tissue. It was confirmed the specific effect of StW on the body of athletes. Grip strength, specific weight of muscle component are predictors of success. The information content of the proposed indices for monitoring the functional state of athletes was confirmed.

Keywords: street workout, physical development, somatotype, bioimpedance method, grip strength.
\end{abstract}

\section{Introduction}

Street workout is currently positioned as a type of healthimproving physical culture and a part of urban culture. It is proposed to evaluate its development from the standpoint

(C) Podrihalo, O., Podrigalo, L., Iermakov, S., Sotnikova-Meleshkina, Z., Sokol, K., Podavalenko, O., Halashko, O., \& Yermakova, T., 2021. of the society development. The analysis of the street workout development concept in Lampung province (Indonesia) makes it possible to assess relations in society, providing opportunities for improving the health of the population (Hanggoro, Kristiyanto, \& Doewes, 2018).

The analysis of historical aspects of exercises with own body mass was carried out (Tomczykowska, 2013). The 
popularity of street workout is stipulated by accessibility, freedom of organizing classes, minimal financial costs. The conclusion is made about the development of a specific value system in youths engaged in street workout.

The similar data were obtained in a study of schoolchildren practicing street workout in the city of Neiva (Monje Mahecha, \& Vanegas García, 2017). These classes were considered a health-forming activity, an element of social integration, aimed at improving the one's body perception.

Street workout is popular among youth (Nadyrov, Mukhiddinov, \& Dayrabayev, 2020). The availability of exercise, the opportunity to train on the open air allows recommending it along with running as a means of a healthy lifestyle development.

The psychosocial profile of street workout athletes is developed (Taipe-Nasimba, Peris-Delcampo, \& Canton Chirivella, 2019). Male students practiced this kind of sport. It is the only type of physical activity for more than half of the participants. The main reasons for training are pleasure, competence and fitness.

The expressed lack of scientific studies devoted to street workout is emphasized (García Herreros, \& Seliva Arroyo, 2019). The high popularity of this new sport is driving an increase in the number of athletes. The lack of specific research does not allow providing comprehensive scientific and methodological support for this sport.

It is proposed to use the method of gamification in street workout to improve control during classes (Pratikto, Arifiansyah, \& Mulyanto, 2020). The creation of mobile applications will provide increased motivation, sufficient density of classes, regulation of loads and prevention of injuries.

The high popularity of street workout is combined with the extremely insufficient scientific support of this sport (Sanchez-Martinez, Plaza, Araneda, Sánchez, \& Almagiâ, 2017). A promising direction is the analysis of the morphological characteristics of athletes.

Based on the foregoing, the purpose of this study is a comparative analysis of the morphological characteristics of street workout athletes with different training experience.

\section{Materials and methods}

\section{Study participants}

The study involved 27 street workout (StW) athletes. The athletes were divided into two groups. Group StW-1 consisted of 13 street workout athletes, age $(15.15 \pm 0.44)$ years. StW-2 group consisted of 14 street workout athletes, age $(16.57 \pm 0.48)$ years. The average training experience of StW-1 was $(1.56 \pm 0.22)$ years and $(2.64 \pm 0.53)$ years of StW-2 respectively.

\section{Study organization}

The study design involved the determination of anthropometric indicators, somatotype components, and the calculation of indices using special formulas. The research program and design were discussed and approved at a meeting of the Commission on Bioethics of the Kharkiv State Academy of Physical Culture.

The evaluation of body mass and body length was conducted in accordance with the international standards
(Marfell-Jones, Olds, Stewart, Lindsay Carter, 2012). Martin's medical anthropometer was used to evaluate body length $(\mathrm{cm})$. Body composition monitor OMRON BF-511 (Japan) was used to evaluate body mass $(\mathrm{kg})$. The level and harmony of physical development was evaluated by the regression method using official standards for children (Serdiuk, 2010) and adults (Tegako, \& Marfina, 2003).

The handgrip $(\mathrm{kg})$ was evaluated in a static mode by handgrip dynamometry. CAMRY EH101 electronic handgrip dynamometer (China) was used. The handgrip dynamometry was determined by the maximum grip frequency in the impulse mode (abs). The electronic device "Kepai" (China) was used. The technique assumed the maximum number of device grips in $10 \mathrm{~s}$. One grip was equivalent to a force of $10 \mathrm{~kg}$.

The somatotype was evaluated using the bioimpedance method. The body composition monitor OMRON BF-511 (Japan) was applied. The specific weight of muscle and adipose tissue (\%), the visceral fat level (\%), the amount of basal metabolism (kcal) was determined. Analysis of somatotype components was evaluated using the Omron Healthcare scale and reference data (Doskin, Keller, \& Muraenko, 1997).

The following morphofunctional indices were measured:

The strength index is the ratio of hand dynamometry $(\mathrm{kg})$ to body weight $(\mathrm{kg})$, expressed as a percentage.

The Impulse index is the ratio of the maximum grip frequency in impulse mode in $10 \mathrm{sec}$ (abs) to body mass (kg), expressed as a percentage.

Static and dynamic grip index is the ratio of hand dynamometry $(\mathrm{kg})$ to the maximum grip frequency in the impulse mode in $10 \mathrm{~s}$ (abs).

\section{Statistical analysis}

Statistical analysis of the data obtained was conducted using licensed MS Excel. Descriptive statistics indicators were determined: arithmetic mean (X), standard deviation $(\mathrm{SD})$ and mean error $(\mathrm{m})$. The significance of the differences was assessed using a nonparametric indicator - the Rosenbaum test $(\mathrm{Q})$, the differences were considered significant at $(p<0.05)$ considering the small size of the groups.

\section{Results}

The obtained results are shown in Table 1 .

The obtained results illustrate the differences in the morphological parameters of the participants. The StW-2 group was characterized by exceeding many indicators. Differences between the groups in terms of age $(\mathrm{Q}=10)$ and training experience $(\mathrm{Q}=8)$ are significant $(\mathrm{p}<0.05)$.

The value of hand dynamometry was higher in the StW2 group for the right $(\mathrm{Q}=8)$ and left $(\mathrm{Q}=6)$ hands $(\mathrm{p}<0.05)$.

More experienced participants had better results in strength indices for the right $(\mathrm{Q}=23)$ and left $(\mathrm{Q}=21)$, impulse indices for the right $(\mathrm{Q}=9)$ and left $(\mathrm{Q}=14)$, static and dynamic left hand grip index $(\mathrm{Q}=14),(\mathrm{p}<0.05)$.

The specific weight of muscles was higher in the StW-2 group $(\mathrm{Q}=6, \mathrm{p}<0.05)$.

The individual analysis of the physical development of the participants made it possible to assess its level and harmony using official standards. The participants with an average level prevailed in group StW-1 $(61.54 \pm 13.49) \%$. The level above average had $(23.08 \pm 11.69) \%$ of athletes. A high 
Podrihalo, O., Podrigalo, L., lermakov, S., Sotnikova-Meleshkina, Z., Sokol, K., Podavalenko, O., Halashko, O., \& Yermakova, T. (2021). Comparative Analysis of Morphological Indicators of Street Workout Athletes With Different Training Experience

Table 1. Indicators of physical development and somatotype

\begin{tabular}{|c|c|c|c|c|c|c|}
\hline \multirow{2}{*}{ Indicators } & \multicolumn{2}{|c|}{ StW-1 $(n=13)$} & \multicolumn{2}{|c|}{ StW-21 (n=14) } & \multirow{2}{*}{ Q } & \multirow{2}{*}{$\mathbf{p}$} \\
\hline & $\mathbf{X}$ & SD & $\mathbf{X}$ & SD & & \\
\hline Body length, cm & 172.00 & 9.44 & 176.50 & 5.90 & 4 & $\mathrm{p}>0.05$ \\
\hline Body mass, kg & 67.14 & 14.21 & 66.10 & 7.36 & 4 & $\mathrm{p}>0.05$ \\
\hline The handgrip of the right hand, kg & 42.38 & 9.29 & 51.26 & 11.21 & 8 & $\mathrm{p}<0.05$ \\
\hline The handgrip of the left hand, kg & 40.09 & 8.78 & 46.04 & 9.51 & 6 & $\mathrm{p}<0.05$ \\
\hline $\begin{array}{l}\text { The maximum grip frequency in impulse mode of the } \\
\text { right hand, the number of times }\end{array}$ & 29.15 & 6.89 & 30.36 & 4.94 & 2 & $\mathrm{p}>0.05$ \\
\hline $\begin{array}{l}\text { The maximum grip frequency in impulse mode of the left } \\
\text { hand, the number of times }\end{array}$ & 27.62 & 7.57 & 26.07 & 7.30 & 2 & $\mathrm{p}>0.05$ \\
\hline Specific weight of adipose tissue, $\%$ & 13.05 & 7.02 & 10.13 & 3.95 & 3 & $\mathrm{p}>0.05$ \\
\hline Specific weight of muscle tissue, $\%$ & 42.02 & 3.26 & 44.11 & 1.91 & 6 & $\mathrm{p}<0.05$ \\
\hline Basal metabolic rate, kcal & 1727.62 & 154.59 & 1702.62 & 104.25 & 3 & $\mathrm{p}>0.05$ \\
\hline Specific weight of visceral fat, \% & 0 & 0 & 0.46 & 1.20 & 0 & $\mathrm{p}>0.05$ \\
\hline Right hand strength index, \% & 64.15 & 13.19 & 77.75 & 16.92 & 23 & $\mathrm{p}<0.01$ \\
\hline Left hand strength index, \% & 60.93 & 13.57 & 70.01 & 14.87 & 21 & $\mathrm{p}<0.01$ \\
\hline Right hand impulse index, kg-1 & 44.65 & 11.41 & 46.19 & 7.16 & 9 & $\mathrm{p}<0.01$ \\
\hline Left hand impulse index, kg-1 & 41.37 & 10.11 & 39.90 & 12.18 & 14 & $\mathrm{p}<0.01$ \\
\hline Index of static and dynamic grip of the right hand, $\mathrm{kg}$ & 1.47 & 0.25 & 1.73 & 0.51 & 14 & $\mathrm{p}<0.01$ \\
\hline Index of static and dynamic grip of the left hand, $\mathrm{kg}$ & 1.51 & 0.32 & 2.01 & 1.22 & 4 & $\mathrm{p}>0.05$ \\
\hline
\end{tabular}

level and a level below the average had $(7.69 \pm 7.39) \%$ of athletes. The proportion of overweight participants in this group was $(61.54 \pm 13.49) \%$. The harmonious physical development had $(38.46 \pm 13.49) \%$ of athletes.

In a group of experienced street workout athletes, the following results were determined. The average level of physical development had $(64.29 \pm 12.81) \%$ participants. The level above average had $(21.43 \pm 10.97) \%$ of participants. The high level and a level below the average had $(7.14 \pm 6.88) \%$ of athletes. The harmonious physical development had $(50.00 \pm 13.36) \%$ of athletes in this group. Overweight had $(42.86 \pm 13.23) \%$ of the participants. The body mass deficit had $(7.14 \pm 6.88) \%$ of athletes. There were no significant differences between the groups in terms of the prevalence of various-grade levels and the harmony of physical development.

The analysis of the characteristics of the somatotype was conducted using the Omron Healthcare scale. It was found that in the group StW-1 $(46.15 \pm 13.83) \%$ had a normal fat content and a level below normal. A high specific weight of fat had $(7.69 \pm 7.39) \%$ of athletes. In the group StW-2, normal fat content had $(30.77 \pm 12.80) \%$ of the participants. A low content of adipose tissue had (69.23 \pm 12.80$) \%$ of athletes. All participants had a high content of muscle tissue.

Basal metabolic results in the groups did not differ significantly.

\section{Discussion}

One of the leading tasks of sports science is the substantiation and development of prediction methods. The purpose of these methods is to determine the probability of achieving success and increasing sportsmanship. Methods of analysis of physical development (Podrigalo, Cynarski, Rovnaya, Volodchenko, Halashko, \& Volodchenko, 2019; Joksimović, Skrypchenko, Yarymbash, Fulurija, Nasrolahi, \& Pantović, 2019; Lilić, Joksimovic, D’Angelo, Karišik, Hamad, \& Gardašević, 2020), psychophysiological characteristics (Volodchenko, Podrigalo, \& Aghyppo, 2017; Wolska et al., 2019), biochemical criteria (Volodchenko, Podrigalo, Iermakov, Żychowska, \& Jagiełło, 2019) can be used for this purpose. The development of predictive techniques is based on various statistical methods (Rovniy, Mulyk, \& Perebeynos, 2018; Kozina, Chebanu, \& Prokopenko, 2018).

Street workout is a new sport. High popularity among youth increases the number of athletes and requires the provision of scientific and methodological support. There are no developed qualification standards in this form. Competitions are primarily a demonstration of various techniques.

The main criteria for dividing street workout athletes are age and training experience. In our opinion, the training experience is the most important. It allows quantitatively assess the skill's level of athletes. An increase in experience increases the technical readiness of athletes, contributes to the development of the necessary technical elements. The established differences according to these criteria make it possible to consider the skill level different and to consider the StW-2 group higher according to this criterion.

The design used - comparing athletes who differ in skill level - is widely used in sports science. A similar approach was used in works (Podrigalo et al., 2020; Volodchenko et al., 2017; Elezi et al., 2021). It allows us to highlight factors and qualities of a higher level. It is they who ensure the achievement of success.

A similar study design was used in works (Kharisov, Nenasheva, \& Aminov, 2017; Kharisov \& Nenasheva, 2018). The authors compared the anthropometric indicators and the composition of the somatotype of students in powerlifting and workout.

The selection of techniques was determined by the goal. A similar set of methods was used to predict metabolic risks by anthropometric parameters and somatotype components (de-Mateo-Silleras et al., 2019; Podrihalo et al., 2020; Kamionka et al., 2020). It coincides with the goal set in this study.

The amount of hand dynamometry should be recognized as an important predictor of success in street workout. A strong grip allows you to perform complex technical elements, provides injury prevention during training. 
The values of the power index clearly show a high level of hand muscles development. All participants had high values of this indicator. It is an important predictor of street workout success and can be used to monitor the health of athletes.

The use of the index method in the analysis of physical development is due to their simplicity, accessibility and information content. The available information allows us to recommend the indices of physical development as screening tests when monitoring the condition of athletes and physically active athletes.

The determined differences in the indices confirm the assumptions made. The methods and indices that we used were tested in works (Podrihalo et al., 2020; Podrihalo et al., 2021). Comparative analysis of street workout and armwrestling athletes confirmed their information content and adequacy for predicting success in these sports. The specificity of the street workout is the need for a strong and fast grip for the implementation of technical elements. In this way, street workout is similar to martial arts (various types of wrestling and arm wrestling). Analysis of hand strength in different modes allows predicting the ability of muscles to perform static and impulse gripping. The use of indices standardizes the factors studied. It is because the indices are relative values.

The similarity of the results of assessing physical development reflects the same orientation of training. The predominance of persons with an average level of development among the participants shows the absence of specific requirements for body length in street workout. The execution of technical elements on sports equipment is most convenient for persons with an average body length. The prevalence of overweight persons among the participants confirms the specificity of the effect of training on the body of athletes. The established disharmony is due to an increase in the specific weight of muscles. An increase in the muscle component of the somatotype occurs because of intense strength training.

The analysis of the characteristics of the somatotype is widely used in sports science to monitor and evaluate the effectiveness of training. It is proposed to determine the profile of a volleyball player by body composition parameters (Campa, \& Toselli, 2018). The dependence of the somatotype on the level of skill was determined. Elite players had more fat-free mass (FFM) and total body water (TBW), and lower fat mass (FM). It coincides with the results of our study.

Similar results were obtained when studying the body composition of judo athletes (da Silva Morais, Mendes Silva Santos, \& de Sousa Sa, 2017). It is concluded that the features of the somatotype are of fundamental importance for increasing physical activity.

The aim of the study (Delaney et al., 2016) was to determine the most effective method for quantifying changes in muscle mass in rugby athletes. The high information content of the analysis of bioelectrical impedance, determination of the muscle mass index and prediction equations based on the thickness of the skinfold has been confirmed.

The results of the bioimpedance method confirm the assumptions made in the analysis of morphological parameters. All participants had a high content of muscle tissue. Most street workout athletes had low or moderate body fat.

Our data are close to the results (Salazar Martinez, \& Jimenez, 2018). The authors analyzed the functional state of young soccer players. The study design also included the determination of the specific weight of body fat using an
OMRON analyzer. It was found that young athletes had an average level of fat typical for this age group (6\%-14\%).

Our results support the available data8. Street workout athletes had balanced mesomorphic somatotype, low fat mass and high muscle development. A high level of strength of the muscles of the shoulder girdle and body trunk was determined

A comparative analysis of street workout athletes and powerlifters is given at (Kharisov et al., 2017, 2018). Street workout athletes had a more proportional body. Powerlifters are characterized by an increase in the circumference of the chest, biceps, shoulders and legs, high values of the body mass index. Somatotype analysis showed that powerlifting athletes have a higher body fat content.

Simultaneously, the comparison allows us to conclude about the importance of using the bioimpedance method. The bioimpedance method confirms the assumptions made in the analysis of physical development, and significantly deepens them. It is consistent with the available literature data (Nascimento-Carvalho et al., 2018). The prospects of using the bioimpedance method for assessing the fitness of athletes in single combats have been confirmed.

The basal metabolic rate reflects the energy expenditures for maintaining the body's homeostasis. The proximity of these values in groups should be assessed as evidence of the stability of the state, the absence of violations. The absence of differences in the values of the basal metabolic rate illustrates the similarity of the metabolism of the participants. Most of the participants are adolescents. This period is characterized by a gradual stabilization of the intensity of growth and development processes.

\section{Conclusions}

The analysis of morphological indicators and somatotype features of street workout athletes with different training experience confirmed the specific effect of the sport on the body of athletes. Athletes with more experience in training have better indicators of hand dynamometry, higher indices of grip strength in various modes. The somatotype is characterized by a decrease in the specific weight of adipose tissue and a high level of muscle tissue. Grip strength, specific weight of muscle and fat components of the somatotype are predictors of success in this type. The information content of the proposed indices, characterizing the grip strength in static and impulse modes, for monitoring the functional state of athletes was confirmed.

\section{Acknowledgments}

The authors express their gratitude to the public organization "Barstylers", trainer Vladyslav Nahorniuk, president Ivan Krylenko for help in organizing the research.

\section{Conflict of interests}

The authors declare no conflict of interest.

\section{References}

Hanggoro, H., Kristiyanto, A., \& Doewes, M. (2018). Calisthenics Activity as Urban Society Culture of Lampung, Indonesia: In Terms of Expectations, Appreciation, and Public Perception of Calisthenics Activity in Street Workout Lampung Community. 
Podrihalo, O., Podrigalo, L., lermakov, S., Sotnikova-Meleshkina, Z., Sokol, K., Podavalenko, O., Halashko, O., \& Yermakova, T. (2021). Comparative Analysis of Morphological Indicators of Street Workout Athletes With Different Training Experience

International Journal of Multicultural and Multireligious Understanding, 5(5), 33.

https://doi.org/10.18415/ijmmu.v5i5.291

Tomczykowska, P. (2013). The modern face of calisthenics. street workout as a new discipline of sport. Journal of Health Sciences, 11, 11-20.

Monje Mahecha, J., \& Vanegas García, J. H. (2017). Sentido de la práctica del Street Workout para los jóvenes escolarizados de la ciudad de Neiva. Entornos, 30(1), 135. https://doi.org/10.25054/01247905.1434

Nadyrov, A., Mukhiddinov, E., \& Dayrabayev, S. (2020). Interest in new sports as a factor in the formation of a sustainable desire for a healthy lifestyle among students. Pedagogy and Psychology, 42(1), 140-146. https://doi.org/10.51889/2020-1.2077-6861.18

Taipe-Nasimba, N., Peris-Delcampo, D., \& Canton Chirivella, E. (2019). Motivos de práctica deportiva, bienestar psicológico e inmigración en practicantes de Street Workout. Rev. Psicol. Deport., 28(2), 135-142. https://doi.org/10.15366/rimcafd2020.79.009

García Herreros, L., \& Seliva Arroyo, N. (2019). Street workout y Calistenia: mucho más que un deporte. Revista Española de Educación Física y Deportes: REEFD, No. Extra 426, 2019 (Ejemplar Dedicado a: XV Congreso Internacional AEISAD), 426(426), 203-209.

Pratikto, D. A., Arifiansyah, F., \& Mulyanto, A. (2020). Interaction Design of Street Workout Application Using Gamification to Support Increased User Motivation to Workout. 2020 7th International Conference on Advance Informatics, Concepts, Theory and Applications (ICAICTA), 1-6. https://doi.org/10.1109/ICAICTA49861.2020.9429034

Sanchez-Martinez, J., Plaza, P., Araneda, A., Sánchez, P., \& Almagiâ, A. (2017). Morphological characteristics of Street Workout practitioners. Nutrición Hospitalaria, 34(1), 122. https://doi.org/10.20960/nh.987

Marfell-Jones, M., Olds, T., Stewart, A., Lindsay Carter, L.E. (2012). ISAK manual, International standards for Anthropometric Assessment. In International Society for the Advancement of Kinanthropometry; Published by The international society for the advancement of kinanthropometry, The University of South Australia Holbrooks Rd, Underdale, SA: Australia. https://doi.org/10.4324/9780203970157

Serdiuk, A.M. (2010). Standards for assessing the physical development of schoolchildren. Kiev. (in Ukrainian).

Tegako, L.I., \& Marfina, O.V. (2003). Practical anthropology. Rostov on Don, Phoenix. (in Russian).

Doskin, V.A., Keller, Kh., \& Muraenko, N.M. (1997). Morphofunctional constants of the child's body. Moscow: Medicine. (in Russian).

Podrigalo, L., Cynarski, W. J., Rovnaya, O., Volodchenko, O., Halashko, O., \& Volodchenko, J. (2019). Studying of physical development features of elite athletes of combat sports by means of special indexes. Ido Movement for Culture. Journal of Martial Arts Anthropology, 19, 51-57. https://doi.org/10.14589/ido.19.1.5

Joksimović, M., Skrypchenko, I., Yarymbash, K., Fulurija, D., Nasrolahi, S., \& Pantović, M. (2019). Anthropometric characteristics of professional football players in relation to the playing position and their significance for success in the game. Pedagogics, Psychology, Medical-Biological Problems of Physical Training and Sports, 23(5), 224-230. https://doi.org/10.15561/18189172.2019.0503

Lilić, A., Joksimovic, M., D’Angelo, S., Karišik, S., Hamad, S., \& Gardašević, N. (2020). Influence of Body Composition Parameters on Anaerobic Strength of Lower Extremities in Female Football Players. Teoriâ ta Metodika Fizičnogo Vihovannâ, 20(4), 256-261.

https://doi.org/10.17309/tmfv.2020.4.09

Volodchenko, O., Podrigalo, L., \& Aghyppo, O. (2017). Comparative Analysis of a functional state of martial arts athletes. Journal of Physical Education and Sport, 17(SI4), 2142-2147.

Elezi, A., Elezi, G., Gontarev, S., \& Georgiev, G. (2021). Secular Trends in Anthropometric Characteristics and HealthRelated Physical Fitness in Macedonian Children: the Makfit Studies. Teoriâ ta Metodika Fizičnogo Vihovannâ, 21(1), 12-18. https://doi.org/10.17309/tmfv.2021.1.02

Volodchenko, O. A., Podrigalo, L. V., Iermakov, S. S., Żychowska, M. T., \& Jagiełło, W. (2019). The Usefulness of Performing Biochemical Tests in the Saliva of Kickboxing Athletes in the Dynamic of Training. BioMed Research International, 2019, 1-7. https://doi.org/10.1155/2019/2014347

Wolska, B., Pujszo, R., Janowska, P., Wojdat, M., Zając, M., \& Pujszo, M. (2019). The specificity of motivations in different combat sports and different lengths of the sports career. Balt J Health Phys Activ, 11(3), 109-116. https://doi.org/10.29359/BJHPA.11.3.11

Rovniy, A., Mulyk, K., \& Perebeynos, V. (2018). Optimization of judoist training process at a stage of gradual decline of sporting achievements. Journal of Physical Education and Sport, 18(4), 2447-2453.

Kozina, Z., Chebanu, O., \& Prokopenko, I. (2018). The implementation of the concept of individualization in training elite female athletes with visual impairment in the sprint. Journal of Physical Education and Sport, 18(1), 282-292.

Podrihalo, O. O., Podrigalo, L. V., Bezkorovainyi, D. O., Halashko, O. I., Nikulin, I. N., Kadutskaya, L. A., \& Jagiello, M. (2020). Analysis of grip strength and somatotype features of armwrestling athletes of different skill levels. Physical Education of Students, 24(2), 120-126. https://doi.org/10.15561/20755279.2020.0208

Kharisov, I.D., Nenasheva, A.V., \& Aminov, A.S. (2017). Assessment of physical fitness indicators in students practicing powerlifting and street workout. Human Sport Medicine, 17(1), 67-78. https://doi.org/10.14529/hsm170107

Kharisov, I., \& Nenasheva, A. (2018). Physical fitness of students practicing various artistic gymnastic routines. Minerva Ortopedica e Traumatologic, 69(3), 49-54. https://doi.org/10.23736/s0394-3410.18.03874-2

de-Mateo-Silleras, B., de-la-Cruz-Marcos, S., AlonsoIzquierdo, L., Camina-Martín, M. A., Marugán-deMiguelsanz, J. M., \& Redondo-del-Río, M. P. (2019). Bioelectrical impedance vector analysis in obese and overweight children. PLOS ONE, 14(1), e0211148. https://doi.org/10.1371/journal.pone.0211148

Kamionka, A., Grzywacz, E., \& Lipowski, M. (2020). Somatotypes of athletes with physical disabilities and the type of activity they undertake. Baltic Journal of Health and Physical Activity, 12(3), 47-60. https://doi.org/10.29359/BJHPA.12.3.05

Podrihalo, O. O., Podrigalo, L. V., Kiprych, S. V., Galashko, M. I., Alekseev, A. F., Tropin, Y. M., Deineko, A. Kh., Marchenkov, M. K., \& Nasonkina, O. Yu. (2021). The comparative analysis of morphological and functional indicators of armwrestling and street workout athletes. Pedagogy of Physical Culture and Sports, 25(3), 188-193. https://doi.org/10.15561/26649837.2021.0307

Campa, F., \& Toselli, S. (2018). Bioimpedance Vector Analysis of Elite, Subelite, and Low-Level Male Volleyball 
Players. International Journal of Sports Physiology and Performance, 13(9), 1250-1253.

https://doi.org/10.1123/ijspp.2018-0039

da Silva Morais, T.M., Mendes Silva Santos, V.R., \& de Sousa Sa, O.M. (2017). Nutritional diagnosis of Piaui men's judo team. RBNE-Revista Brasileira de Nutricao Esportiva, 11(66), 682-688.

Delaney, J. A., Thornton, H. R., Scott, T. J., Ballard, D. A., Duthie, G. M., Wood, L. G., \& Dascombe, B. J. (2016). Validity of Skinfold-Based Measures for Tracking Changes in Body Composition in Professional Rugby League Players. International Journal of Sports Physiology and Performance, 11(2), 261-266.

https://doi.org/10.1123/ijspp.2015-0244

Salazar Martinez, J.L., \& Jimenez, T.J.O. (2018). Evaluation of maximum oxygen consumption $\left(\mathrm{VO}_{2} \mathrm{max}\right)$ and percentage of fat in young footballers. Viref-Revista de Educacion Fisica, 7(1), 50-86.

Nascimento-Carvalho, B. do, Mayta, M. A. C., Izaias, J. E., Doro, M. R., Scapini, K., Caperuto, E., Grilletti, J. V. F., \& Sanches, I. C. (2018). Cardiac sympathetic modulation increase after weight loss in combat sports athletes. Revista Brasileira de Medicina Do Esporte, 24(6), 413-417. https://doi.org/10.1590/1517-869220182406182057

\title{
ПОРІВНЯЛЬНИЙ АНАЛІЗ МОРФОЛОГІЧНИХ ПОКАЗНИКІВ АТЛЕТІВ ВУЛИЧНОГО ВОРКАУТУ IЗ РІЗНИМ ТЕРМІНОМ ЗАНЯТЬ
}

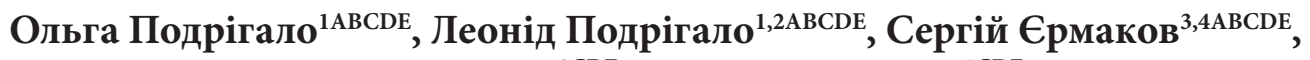 \\ Жанна Сотнікова-Мелешкіна ${ }^{2 \mathrm{CDE}}$, Костянтин Сокол $^{5 \mathrm{CDE}}$, Олександр Подаваленко $^{1 \mathrm{CDE}}$, \\ Олександр Галашко ${ }^{6 \mathrm{CDE}}$, Тетяна Єрмакова ${ }^{4 \mathrm{ACD}}$
}

${ }^{1}$ Харківська державна академія фізичної культури

${ }^{2}$ Харківський національний університет імені В. Н. Каразіна

${ }^{3}$ Гданський університет фізичного виховання і спорту

${ }^{4}$ Харківська державна академія дизайну та мистецтв

${ }^{5}$ Харківський національний медичний університет

${ }^{6}$ Державний біотехнологічний університет

Авторський вклад: А - дизайн дослідження; В - збір даних; С - статаналіз; D - підготовка рукопису; Е - збір коштів

Реферат. Стаття: 7 с., 1 табл., 31 джерело.

Мета роботи - здійснити порівняльний аналіз морфологічних особливостей атлетів вуличного воркауту з різним стажем занять.

Матеріали і методи. У дослідженні брали участь 27 атлетів вуличного воркауту (StW). Група StW-1 - 13 атлетів $(15,15 \pm 0,44)$ років, стаж занять $(1,56 \pm 0,22)$ років; StW-2 - 14 атлетів $(16,57 \pm 0,48)$ років, стаж занять $(2,64 \pm 0,53)$ років. Визначали довжину та масу тіла, рівень та гармонійність фізичного розвитку регресійним методом. Силу хвата визначали кистьовим динамометром Camry EH101 (China). Динамічну силу хвата визначали за максимальною частотою хвата за 10 сек пристроєм "Кераi" (China). Визначали вміст м'язової та жирової тканини монітором складу тіла OMRON BF-511 (Японія).

Результати. Встановлено, що силовий індекс у StW1 був понад 60\%, у StW-2 - понад 70\%. У StW-2 була достовірно вище кістьова динамометрія, силовий та імпульсний індекси обох руки, індекс статичного та динамічного хвату лівої руки, питома вага м'язів. У StW-1 середній рівень фізичного розвитку мали $(61,54 \pm 13,49) \%$, вище середнього - $(23,08 \pm 11,69) \%$. Гармонійний фізичний розвиток встановлено у $(38,46 \pm 13,49) \%$. У StW-2 середній рівень фізичного розвитку мали $(64,29 \pm 12,81) \%$, вище середнього - $(21,43 \pm 10,97) \%$. Гармонійний фізичний розвиток встановлено у $(50,00 \pm 13,36) \%$ учасників. У StW-1 $(46,15 \pm 13,83) \%$ мали нормальний вміст жиру і рівень жиру нижче норми. У групі StW-2 нормальний вміст жиру мали $(30,77 \pm 12,80) \%$, низький вміст - $(69,23 \pm 12,80) \%$.

Висновки. Усі учасники характеризувалися високим вмістом м'язової тканини. Підтверджено специфічний вплив виду спорту на організм атлетів. Сила хвата, питома вага м'язового компонента $€$ предикторами успіху. Запропоновані індекси $є$ інформативними для моніторингу функціонального стану атлетів.

Ключові слова: вуличний воркаут, фізичний розвиток, соматотип, біоімпедансний метод, сила стиснення. 
Podrihalo, O., Podrigalo, L., lermakov, S., Sotnikova-Meleshkina, Z., Sokol, K., Podavalenko, O., Halashko, O., \& Yermakova, T. (2021). Comparative Analysis of Morphological Indicators of Street Workout Athletes With Different Training Experience

\section{Information about the authors:}

Podrihalo Olha: rovnayaolga77@ukr.net; http://orcid.org/0000-0003-1519-5632; Department of Biological Discipline, Kharkiv State Academy of Physical Culture; Klochkivska St, 99, Kharkiv, 61022, Ukraine.

Podrigalo Leonid: leonid.podrigalo@gmail.com; http://orcid.org/0000-0002-7893-524X; Department of Medical Discipline, Kharkiv State Academy of Physical Culture; Klochkivska St, 99, Kharkiv, 61022, Ukraine.

Iermakov Sergii: sportart@gmail.com; http://orcid.org/0000-0002-5039-4517; Department of Sports, Gdansk University of Physical Education and Sport; Kasimir Gorskogo St, 1, 80-336 Gdansk, Poland. Kharkiv State Academy of Design and Arts; Mystetstv St, 8, Kharkiv, 61002, Ukraine.

Sotnikova-Meleshkina Zhanna: zhanna.univer@gmail.com; http://orcid.org/0000-0001-5534-8264; Department of Hygiene and Social Medicine, V.N. Karazin Kharkiv National University, Svobody Sq., 4, Kharkiv, 61022, Ukraine.

Sokol Konstantin: sokolvk@ukr.net; http://orcid.org/0000-0001-8363-8402; Department of Social Medicine, Kharkiv National Medical University; 4 Nauky Avenue, 61022, Kharkiv, Ukraine.

Podavalenko Olexandr: alekontp@ukr.net; http://orcid.org/0000-0001-9143-3351; Department of Medical Discipline, Kharkiv State Academy of Physical Culture; Klochkivska St, 99, Kharkiv, 61022, Ukraine.

Halashko Olexsandr: alexgalashko73@gmail.com; https://orcid.org/0000-0003-0829-2186; Department of Physical Culture, State Biotechnological University, Alchevskykh St, 44, Kharkiv, 61002, Ukraine

Yermakova Tetiana: yermakova2015@gmail.com; https://orcid.org/0000-0002-3081-0229; Department of Pedagogy, Kharkiv State Academy of Design and Arts; Mystetstv St, 8, Kharkiv, 61002, Ukraine.

Cite this article as: Podrihalo, O., Podrigalo, L., Iermakov, S., Sotnikova-Meleshkina, Z., Sokol, K., Podavalenko, O., Halashko, O., \& Yermakova, T. (2021). Comparative Analysis of Morphological Indicators of Street Workout Athletes With Different Training Experience. Teoriâ ta Metodika Fizičnogo Vihovannâ, 21(4), 343-349. https://doi.org/10.17309/tmfv.2021.4.09

Received: 11.10.2021. Accepted: 02.12.2021. Published: 25.12.2021

This work is licensed under a Creative Commons Attribution 4.0 International License (http://creativecommons.org/licenses/by/4.0). 